\title{
SPRAWOZDANIE Z XIII KONFERENCJI
}

\section{AKADEMICKIEGO STOWARZYSZENIA \\ PSYCHOLOGII EKONOMICZNEJ}

\author{
Poznań, 8-10 maja 2019 roku \\ Elżbieta Kubińska \\ Uniwersytet Ekonomiczny w Krakowie
}

XIII Konferencja Akademickiego Stowarzyszenia Psychologii Ekonomicznej odbyła się po raz pierwszy w Poznaniu w dniach 8-10 maja 2019 roku, a tegorocznym organizatorem był tamtejszy Wydział Zamiejscowy SWPS Uniwersytetu Humanistycznospołecznego. Głównym organizatorem konferencji i zarazem przewodniczącym Komitetu Organizacyjnego był dr Maciek Kościelniak, a przewodniczącą Komitetu Naukowego została dr hab. prof. SWPS Agata Gąsiorowska. Jak co roku konferencja zgromadziła uczestników z ośrodków naukowych z całej Polski, zainteresowanych szeroko rozumianą psychologią ekonomiczną. Zgłoszone referaty podzielono na sześć sekcji tematycznych (Decyzje, Zachowania konsumenckie/reklama, Moralność/ Prawo, Ekonomia behawioralna i giełda, Psychologia pieniędzy i Procesy poznawcze) oraz dwie sesje pięciominutowych referatów.

Pierwszego dnia konferencji uczestnicy mieli przyjemność wysłuchać wykładu plenarnego zatytułowanego Prawo i psychologia $w$ ochronie marki na rynku gospodarczym, wygłoszonego przez prof. dr. hab. Andrzeja Falkowskiego. Przedstawiono w nim studia przypadków i wyniki badań eksperymentalnych, wpisujące się w kierunek zintegrowanego podejścia prawnego i psychologicznego w analizie niebezpieczeństwa wprowadzenia w błąd konsumentów na zasadzie podobieństwa znaków towarowych.

Pierwszego dnia miała miejsce również specjalna sesja z okazji 80. urodzin prof. dr. hab. Tadeusza Tyszki. Do udziału w sesji zostali zaproszeni długoletni współpracownicy Solenizanta, wśród których znaleźli się koledzy i koleżanki ze studiów, uczestnicy seminariów, współautorzy artykułów i książek, a także pracownicy Centrum Psychologii Ekonomicznej i Badań Decyzji Akademii Leona Koźmińskiego. Wśród prelegentów byli między innymi: prof. dr hab. Tomasz Zaleśkiewicz, prof. dr hab. Janusz Grzelak, prof. dr hab. Grzegorz Lissowski, prof. dr hab. Maryla Goszczyńska, prof. dr hab. Maciej Dymkowski, prof. dr hab. Andrzej Falkowski, 
prof. dr hab. Czesław Nosal, dr hab. Agata Gąsiorowska, dr Anna Macko, dr Katarzyna Idzikowska, dr Łukasz Markiewicz, dr Marcin Malawski, dr Artur Domurat i dr Kornel Świątnicki.

Pierwszym prelegentem był prof. Tomasz Zaleśkiewicz, który przedstawił dorobek Solenizanta, omawiając pokrótce książki, których prof. Tyszka jest autorem, współautorem lub redaktorem. Prezentację rozpoczęła pierwsza publikacja prof. Tyszki zatytułowana Konflikty i strategie. Niektóre zastosowania teorii gier (Wydawnictwo Naukowo-Techniczne, Warszawa 1978), a następna - Analiza decyzyjna i psychologia decyzji (PWN, Warszawa 1986) - została określona mianem biblii uczestników konferencji ASPE. Kolejne książki Solenizanta to Psychologiczne pułapki oceniania i podejmowania decyzji (Gdańskie Wydawnictwo Psychologiczne, Gdańsk 1999) oraz Psychologia zachowań ekonomicznych (PWN, Warszawa 1997). Wśród książek stworzonych we współautorstwie wymieniono Racjonalność decyzji (Polskie Wydawnictwo Ekonomiczne, Warszawa 2001), napisaną wraz z prof. dr hab. Tomaszem Zaleśkiewiczem, oraz Psychologię zachowań konsumenckich (Gdańskie Wydawnictwo Psychologiczne, Gdańsk 2001), stworzoną wraz z prof. dr hab. Andrzejem Falkowskim. Ostatnią do tej pory (stan na rok 2019) książką prof. Tyszki są Decyzje. Perspektywa psychologiczna i ekonomiczna (Wydawnictwo Naukowe Scholar, Warszawa 2010), a publikacja ta została doceniona przez Ministra Nauki i Szkolnictwa Wyższego poprzez przyznanie nagrody w 2012 roku. Prof. Zaleśkiewicz przypomniał także tytuły związane z obszarami mniej popularnymi wśród uczestników konferencji, tj. Psychologia i bezpieczeństwo pracy (Instytut Psychologii PAN, Warszawa 1992, pod red. Tadeusza Tyszki). Niektóre książki autorstwa prof. Tyszki są zakwalifikowane jako naukowe i popularnonaukowe, a czasem jako poradniki. Trafność zaliczenia ich do takiej kategorii potwierdził prof. Zaleśkiewicz, opowiadając o pasażerce pociągu relacji Warszawa-Wrocław, która przedstawiła się jako przedsiębiorca która po lekturze rozdziału książki Racjonalność decyzji: pewność i ryzyko (przez ramię prof. Z.) stwierdziła, że manuskrypt jest bardzo interesujący, a prezentowane w nim treści - wyjątkowo przydatne. Prof. Zaleśkiewicz wspomniał również o wyjątkowej tężyźnie fizycznej prof. Tadeusza Tyszki, którą zawstydzał swoich kolegów, oraz o wielkim zamiłowaniu do przyrody. Prof. Lissowski, podejmując próbę określenia początku naukowej znajomości z prof. Tyszką, wskazał na seminarium prof. Klemensa Szaniawskiego dotyczące podejmowania decyzji, które później opisali wspólnie w numerze Prakseologii poświęconym pamięci prof. Szaniawskiego. Prof. Lissowski wspomniał także o pracy nad zasadami sprawiedliwości dystrybutywnej, której owocem jest artykuł opublikowany w 1991 roku w czasopiśmie Journal of Conflict Resolution, stanowiący jeden z najczęściej cytowanych artykułów autorów ${ }^{1}$. Prof. Janusz

1 T. Tyszka, G. Lissowski, W. Okrasa (1991), Principles of distributive justice: Experiments on preferences in Poland and America. Journal of Conflict Resolution, 35, 98-119. 
Grzelak, opowiadając o wspólnej pracy naukowej nad grami w warunkach współzależności, słowami $Z$ Tadeuszem ciężko było nieciężko pracować wskazał na wyjątkową zdolność Solenizanta do motywowania współpracowników do efektywnej pracy. Uczestnicy konferencji będą również pamiętać o wykładzie na temat nieistnienia osobowości oraz o niespotykanej odwadze i brawurze w zorganizowaniu w czasach PRL wyjścia do kina, zakładającego zachowanie dyrektora kina i kasjerki zgodne ze strategią minimaks. Prof. Maryla Goszczyńska trafnie określiła życie prof. Tadeusza Tyszki, mówiąc, że jest to życie splecione z nauką, nauka spleciona z życiem. Oprócz przywołania licznych anegdot wspomniała także, że w 1981 roku nikt w Polsce jeszcze nie słyszał o psychologii ekonomicznej, a prof. Tadeusz Tyszka miał już wtedy konto bankowe, na które jego koledzy z roku mogli wpłacać składki. Prof. Tyszka był także człowiekiem czynu, człowiekiem dobrej roboty - i to nie tylko z racji zatrudnienia w Instytucie Prakseologii Polskiej Akademia Nauk. Dodała, że pałacyk Ustronie pod Wrocławiem gościł autorów rozdziałów książki Psychologia i bezpieczeństwo pracy (pod red. Tadeusza Tyszki), a oni - ryzykując brak spaceru i niemożność zagrania wieczorem w brydża - byli zmotywowani ukończyć swoją pracę na czas. Prof. Czesław Nosal stwierdził, że Tadeusz ma wyjątkowa skłonność do tautologii i jako przykład podał myśl wypowiedzianą przez Solenizanta, że wszelka aktywność nie jest biernościq. Prof. Andrzej Falkowski podał przykłady na pionierską treść książek prof. Tyszki, ale także na bezpośredni i obrazowy język recenzji. Dr hab. Agata Gąsiorowska słowami: jak trzeba być wytrwatym, żeby w czasach kiedy dostęp do nauki byt o wiele trudniejszy, uczestniczyć $w$ światowym nurcie badań podziękowała Solenizantowi za dawanie przykładu wytrwałości w prowadzeniu badań. Za wprowadzenie do międzynarodowego środowiska badawczego podziękowała dr hab. Joanna Sokołowska. O wytrwałości w pracy naukowej prof. Tyszki traktował list dr. hab. Piotra Zielonki odczytany przez prof. dr. hab. Tomasza Zaleśkiewicza. Nawiązywał on do prawdopodobieństw bazowych pożaru w pracowni komputerowej i palonych liści w ogrodzie.

Walne Zgromadzenie Akademickiego Stowarzyszenia Psychologii Ekonomicznej podjęło decyzję o przyznaniu prof. Tadeuszowi Tyszce statusu honorowego członka. Stowarzyszenie powstało w 2008 roku z inicjatywy Solenizanta, tworząc formalną strukturę łączącą badaczy związanych z szeroko pojętą psychologią ekonomiczną. Prof. Tyszka został wybrany na pierwszego przewodniczącego ASPE i był organizatorem pierwszej konferencji Psychologia Ekonomiczna w 2007 roku na Akademii Leona Koźmińskiego.

Podczas uroczystej kolacji konferencyjnej wręczono nagrodę w konkursie Szare Komórki 2019 za najlepszą studencką pracę badawczą z zakresu psychologii ekonomicznej. Nagrodę otrzymała mgr Nikoletta Brniak, była studentka II Wydziału Psychologii SWPS Uniwersytetu Humanistycznospołecznego, za pracę magisterską zatytułowaną Wpływ zapachu na deklarowane sposoby wydawania pieniędzy. 
Laureatem konkursu Ariadna Impresiv 2019 na najlepszą prezentację przedstawioną na konferencji został Kamil Fuławka z wrocławskiego Wydziału Zamiejscowego SWPS Uniwersytetu Humanistycznospołecznego za referat pod tytułem Modelowanie decyzji ryzykownych z niepienięznymi konsekwencjami. Referat został zgłoszony wspólnie z Thorstenem Pachurem z Max Planck Institute for Human Development. Laureat konkursu przedstawił w nim wyniki dwóch eksperymentów, z których wynika, że ludzie dostosowują strategię przetwarzania informacji opcji ryzykownej do najgorszego możliwego wyniku w danym problemie decyzyjnym, przy czym istotną rolę w wyborze strategii odgrywa ocena afektywna konsekwencji. W przypadku problemów z silnie afektywnymi wynikami respondenci stosują strategie niekompensacyjne, natomiast dla problemów z względnie słabo afektywnymi wynikami - strategie zbliżone do kompensacyjnych.

Konferencja zakończyła się warsztatem statystycznym poprowadzonym przez dr. Maksymiliana Bieleckiego z SWPS Uniwersytetu Humanistycznospołecznego w Warszawie. Warsztat poświęcony był mieszanym modelom liniowym w środowisku $\mathrm{R}$ (linear mixed models) umożliwiającym weryfikację modeli pochodzących z badań, w których zakładać można występowanie współzależności między losowo zmierzonymi czynnikami. Warsztat cieszył się dużą popularnością wśród uczestników konferencji.

W imieniu głównego organizatora kolejnej konferencji - dr hab. Alicji Grochowskiej, zastępcy dyrektora Instytutu Psychologii Ekonomicznej Wydziału Psychologii SWPS Uniwersytetu Humanistycznospołecznego w Warszawie - serdecznie zapraszamy do udziału w XIV Konferencji Akademickiego Stowarzyszenia Psychologii Ekonomicznej. Zachęcamy czytelników „Decyzji” do zgłaszania wystąpień z ciekawymi wynikami własnych prac badawczych, ale również do przekazania informacji studentom i zachęcania ich do zgłoszenia swoich prac na konkurs Szare Komórki 2020. Zgodnie z regulaminem przyjmowane są prace licencjackie, magisterskie lub doktorskie ukończone maksymalnie dwa lata przed terminem zgłoszeń. Do zobaczenia w Białowieży w maju 2020 roku! 